\title{
PERAN BANK SEBAGAI LEMBAGA PERANTARA (INTERMEDIARY) DITINJAU DARI UNDANG-UNDANG NOMOR 10 TAHUN 1998
}

\author{
SUMARNI \\ Dosen Fakultas Hukum Universitas Islam Al-Azhar Mataram \\ e-mail: sumarni@gmail.com
}

\begin{abstract}
ABSTRAK
Tujuan penelitian ini adalah untuk mengetahui bagaimanakan peran bank sebagai lembaga perantara (intermediary) ditinjau dari Undang-Undang Nomor 10 Tahun 1998. Untuk menjawab rumusan masalah penulis menggunakan penelitian hukum normatif yaitu dengan mengkaji/ menganalisis bahan hukum primer dan bahan hukum sekunder dengan memahami hukum sebagai seperangkat peraturan atau norma-norma positif di dalam sistem perundang-undangan yang mengatur berkaitan dengan masalah yang diteliti. Berdasarkan hasil penelitian diperoleh kesimpulan bahwa bank sebagai salah satu lembaga keuangan yang paling penting dan memiliki peranan besar dalam kehidupan masyarakat memiliki fungsi yakni Pertama adalah sebagai pedagang dana (money lender) yaitu wahana yang dapat menghimpun dan menyalurkan dana masyarakat secara efektif dan efisien. Bank menjadi tempat untuk penitipan, dan penyimpanan uang yang dalam prakteknya sebagai tanda penitipan dan penyimpanan uang tersebut, maka kepada penitip dan penyimpan diberikan selembar kertas dan tanda bukti. Sedangkan dalam fungsinya sebagai penyalur dana, maka bank memberikan kredit atau memasukkannya kedalam bentuk surat-surat berharga. Kedua adalah sebagai lembaga yang melancarkan transaksi perdagangan, dan pembayaran uang. Bank bertindak sebagai penghubung antara nasabah yang satu dengan yang lainnya jika keduanya melakukan transaksi. Dalam hal ini kedua orang tersebut tidak secara langsung melakukan pembayaran tetapi cukup memerhatikan pada bank untuk menyelesaikannya.
\end{abstract}

Kata Kunci: Bank, Lembaga Perantara

\section{ABSTRACT}

The purpose of this study was to determine the role of banks as intermediary institutions in terms of Law Number 10 of 1998. To answer the problem formulation, the author uses normative legal research, namely by studying / analyzing primary and secondary legal materials by understanding law as a set of rules or positive norms in the statutory system that governs the issues under study. Based on the results of the study, it is concluded that the bank as one of the most important financial institutions and has a major role in people's lives has a function, namely First is as a fund trader (money lender), namely a vehicle that can collect and channel public funds effectively and efficiently. The bank becomes a place for safekeeping and safekeeping of money, which in practice serves as a sign of safekeeping and safekeeping of the money, so the custodian and the depositor shall be given a sheet of paper and proof. Meanwhile, in its function as a channel of funds, the bank provides credit or includes it in the form of securities. The second is as an institution that launches trade transactions and payments of money. The bank acts as a liaison between one customer and another if both make transactions. In this case the two persons do not directly make the payment but pay enough attention to the bank to settle it.

Keywords: Bank, Intermediary Institutions.

\section{PENDAHULUAN}

Pembangunan nasional merupakan upaya pembangunan yang berkesinambungan dalam rangka mewujudkan masyarakat yang adil dan makmur berdasarkan Pancasila dan Undang-undang Dasar 1945, Pembangunan yang dilakukan dari segala aspek serta meliputi penyelenggaraan negara yaitu lembagalembaga negara untuk mensejahterakan rakyat. 
Indonesia telah mengalami krisis yang multidimensi, yang berlangsung pada pertengahan tahun 1997 yang merupakan krisis terparah di kawasan Asia. Krisis tersebut mencakup krisis moneter dan krisis ekonomi, yang telah menimbulkan rusaknya tatanan ekonomi dan keuangan, meningkatnya tingkat pengangguran, menurunnya tingkat daya beli masyarakat, serta tingginya jumlah penduduk yang berada di bawah garis kemiskinan. Hal ini disebabkan karena banyaknya kelemahan dalam sistem perbankan di Indonesia yang mekanisme pengendalian dan pengawasan dari pemerintah tidak efektif dan tidak mampu mengikuti cepatnya pertumbuhan sektor perbankan. Yang lebih parah, hampir tidak ada penegakan hukum terhadap bank-bank yang melanggar ketentuan, khususnya dalam kasus peminjaman ke kelompok bisnisnya sendiri, konsentrasi pinjaman pada pihak tertentu, dan pelanggaran kriteria layak kredit. Pada waktu yang bersamaan banyak sekali bank yang sesungguhnya tidak bermodal cukup (undercapitalized) atau kekurangan modal, tetapi tetap dibiarkan beroperasi. Ketika nilai rupiah mulai terdepresiasi, sistem perbankan tidak mampu menempatkan dirinya sebagai "Peredam Kerusakan", tetapi justru menjadi korban langsung akibat neracanya yang tidak sehat. Krisis ekonomi regional menyebabkan dilakukannya restrukturisasi di segala sektor baik perbankan maupun perusahaan dalam bidang lain di Indonesia. Namun slah satu lembaga yang lebih dominan dalam pemulihan sistem perekonomian yaitu perbankan. Kelembagaan bank menurut Undang-Undang Nomor 10 Tahun 1998 tentang Perbankan adalah :

a. Bank Umum adalah: "Bank yang melaksanakan kegiatan usaha secara konvensional dan atau berdasarkan Prinsip Syariah yang dalam kegiatanya memberikan jasa dalam lalu lintas pembayaran."

b. Bank Perkreditan Rakyat adalah: "Bank yang melaksanakan kegiatan usaha secara konvensional atau berdasarkan Prinsip Syariah yang dalam kegiatannya tidak memberikan jasa dalam lalu lintas pembayaran."

Sedangkan dalam operasionalnya, usaha bank yang dapat dilakukan oleh bank umum dan bank perkreditan rakyat, sebagai berikut :

Usaha Bank umum meliputi (Undang-Undang Nomor 10 Tahun 1998) :

1. Menghimpun dana dari masyarakat dalam bentuk simpanan berupa giro, deposito berjangka, sertifikat deposito, tabungan, dan/atau bentuk lainnya yang dipersamakan dengan itu;

2. Memberikan kredit ;

3. Menerbitkan surat pengakuan hutang ;

4. Membeli, menjual atau menjamin atas risiko sendiri maupun untuk kepentingan dan perintah nasabahnya :

a. Surat-surat wesel termasuk wesel yang diakseptasi oleh bank yang masa berlakunya tidak lebih lama daripada kebiasaan dalam perdagangan surat-surat dimaksud ;

b. Surat pengakuan hutang dan kertas dagang lainnya yang masa berlakunya tidak lebih lama dari kebiasaan dalam perdagangan surat-surat dimaksud.

c. Kertas perbendaharaan Negara dan surat jaminan pemerintah ;

d. Sertifikat Bank Indonesia (SBI) ;

e. Obligasi ;

f. Surat dagang berjangka waktu sampai dengan 1 (satu) tahun ;

g. Instrument surat berharga lain yang berjangka waktu sampai dengan 1 (satu) tahun.

h. Memindahkan uang baik untuk kepentingan sendiri maupun untuk kepentingan nasabah ;

5. Menempatkan dana pada, meminjam dana dari, atau meminjamkan dana kepada bank lain, baik dengan menggunakan surat, sarana telekomunikasi maupun dengan wesel tunjuk, cek atau sarana lainnya;

6. Menerima pembayaran dari tagihan atas surat berharga dan melakukan perhitungan dengan atau antara pihak ketiga ;

7. Menyediakan tempat untuk menyimpan barang dan surat berharga ;

8. Melakukan penempatan dana dari nasabah kepada nasabah lainnya dalam bentuk surat berharga yang tidak tercatat di bursa efek ;

9. Membeli melalui pelelangan agunan baik semua maupun dalam hal debitur tidak memenuhi kewajibannya kepada bank, dengan ketentuan agunan yang dibeli tersebut wajib dicairkan secepatnya;

10. Melakukan kegiatan anjak piutang, usaha kartu kredit dan kegiatan wali amanat ;

11. Melakukan pembiyayaan bagi nasabah berdasarkan prinsip bagi hasil sesuai dengan ketentuan yang ditetapkan dalam Peraturan Pemerintah;

12. Melakukan kegiatan lain yang lazim dilakukan oleh bank sepanjang tidak bertentangan dengan undangundang yang berlaku.

Usaha bank perkreditan rakyat meliputi (Undang-Undang 10 Tahun 1998) :

1. Menghimpun dana dari masyarakat dalam bentuk simpanan berupa deposito berjangka, tabungan, dan/atau bentuk lainnya yang dipersamakan dengan itu.

2. Memberikan kredit. 
3. Menyediakan pembiyaan bagi nasabah berdasarkan prinsip bagi hasil sesuai dengan ketentuan yang ditetapkan dalam Peraturan Pemerintah.

4. Menempatkan dananya dalam bentuk Sertifikat Bank Indonesia (SBI), deposito berjangka, sertifikat deposito dan/atau tabungan pada bank lain.

Sedangkan bentuk usaha yang dilarang dilakukan oleh bank umum meliputi :

1. Melakukan penyertaan modal, kecuali sebagaimana dimaksud dalam pasal 7 huruf $\mathrm{b}$ dan huruf $\mathrm{c}$.

2. Melakukan usaha perasuransian.

3. Melakukan usaha lain di luar kegiatan usaha sebagaimana dimaksud dalam pasal 6 dan pasal 7.

Dan Bank Perkreditan Rakyat dilarang dalam :

1. Menerima simpanan berupa giro dan ikut serta dalam lalu lintas pembayaran.

2. Melakukan kegiatan usaha dalam valuta asing.

3. Melakukan penyertaan modal.

4. Melakukan usaha perasuransi.

5. Melakukan usaha di luar kegiatan usaha sebagaimana dimaksud dalam pasal 13

Peran yang dimiliki oleh Bank dan lembaga keuangan bukan bank yang sangat strategis dimana menjadi wahana yang mampu menghimpun dan menyalurkan dana masyarakat secara efektif dan efisien ke arah peningkatan taraf hidup rakyat yang lebih baik. Bank dan lembaga keuangan bukan bank merupakan perantara keuangan (financial intermediaries) sebagai prasarana pendukung yang amat vital untuk menunjang kelancaran perekonomian. Bank dan lembaga keuangan bukan bank pada dasarnya memiliki fungsi mentransfer dana-dana (loanable funds) dari penabung atau unit surplus (lenders) kepada peminjam (borrowers) atau unit deficit. Dana tersebut dialokasikan dengan negosiasi antara pemilik dana dan pemakai dana melalui pasar uang dan pasar modal. Produk yang ditransaksikan berupa sekuritas primer (saham, obligasi, promes, dan sebagainya) serta sekuritas sekunder (giro, tabungan, deposito, polis, program pensiun, saham, dan sebagainya). Sekuritas sekunder ini diterbitkan oleh bank dan lembaga keuangan bukan bank, ditawarkan kepada unit surplus.

Pada Undang-Undang Perbankan Nomor 10 Tahun 1998 telah ditegakkan prinsip bank. Berarti, rahasia bank bukan sekedar kebijaksanaan, tetapi juga bersifat "normatif" karena merupakan ketentuan hukum yang secara tegas dirumuskan dalam Undang-Undang. Dengan demikian rahasia bank merupakan "hukum positif". Bank dan semua pihak termasuk Dewan Moneter, wajib "memelihara konfidensial (Secrecy)". Yang menyangkut keuangan dan hal-hal lain dari nasabah. Ketentuan rahasia bank ini diatur menjadi hukum positif dalam pasal 40 Undang-Undang Nomor 10 Tahun 1998 yang berbunyi : "Bank dilarang memberi keterangan yang tercatat pada bank tentang keadaan keuntungan dan hal-hal lain daripada nasabahnya yang wajib dirahasiakan oleh bank menurut kelaziman."

Jika ketentuan pasal 40 dihubungkan dengan penjelasannya, dapat dikemukakan beberapa prinsip rahasia bank yang harus dipedomani yaitu:

\section{Rahasia Bank Merupakan Hukum Positif Bersifat Memaksa}

Rahasia bank bernilai normatif dalam bentuk hukum positif. Bentuk hukum positifnya diatur dalam pasal 40 Undang-Undang Nomor 10 tahun 1998. Hukum positifnya bersifat "memaksa", sebab apabila dilanggar akan terkena atau diancam dengan hukum pidana maupun perdata. Dari segi pidana diancam oleh pasal 47 Undang-undang Nomor 10 tahun 1998 dalam bentuk gabungan pidana "penjara" dan "denda":

a. Siapa saja yang melanggar pasal 41 atau 42, dipidana "Penjara" dan "denda" maksimum 3 tahun dan 3 miliar rupiah.

b. Anggota direksi, komisaris atau pegawai yang melanggar pasal 40, dipidana penjara dan denda maksimal 2 tahun dan denda 2 milyar rupiah.

Dari Segi perdata, dapat dituntut ganti rugi atas alasan Perbuatan Melawan Hukum (Tortlaw), karena pelaku melanggar ketentuan pasal 40 Undang-Undang Nomor 10 Tahun 1998. Atas adanya pelanggaran pasal 40 tersebut maka pelaku dapat diancam pasal 1365 KUHPerdata dimana setiap perbuatan yang melanggar hukum dan membawa kerugian kepada orang lain, mewajibkan orang yang menimbulkan kerugian itu karena kesalahannya untuk mengganti kerugian tersebut.

Menurut pasal 1 Ayat (28) dari Undang-Undang Perbankan, yang dimaksud dengan rahasia bank adalah segala sesuatu yang berhubungan dengan keterangan mengenai nasabah, penyimpan dan simpanannya. Jadi Undang-Undang Nomor 10 Tahun 1998 tentang Perbankan, mempertegas dan mempersempit pengertian rahasia bank dibandingkan dengan ketentuan dalam pasal-pasal dari undangundang sebelumnya, yaitu Undang-Undang Nomor 7 Tahun 1992, yang tidak khusus menunjukkan rahasia bank kepada nasabah deposito saja.

Dari pengertian yang diberikan oleh Pasal 1 Ayat (28) dalam Undang-Undang Nomor 10 Tahun 1998 dapat disimpulkan unsur-unsur dari rahasia bank itu, yaitu sebagai berikut: 
a. Rahasia bank tersebut berhubungan dengan segala sesuatu yang mengenai nasabah penyimpan dan simpanannya.

b. Hal tersebut "wajib" dirahasiakan oleh bank, kecuali termasuk ke dalam kategori pengecualian berdasarkan prosedur dan peraturan perundang undangan yang berlaku.

c. Pihak yang dilarang membuka rahasia bank adalah pihak bank sendiri dan/atau terafiliasi.

\section{Pihak-Pihak Yang Berkewajiban Menjaga Rahasia Bank}

Dari bunyi Pasal 47 Ayat (2) dapat diambil kesimpulan bahwa pihak-pihak yang berkewajiban menjaga bank adalah:

a. Anggota Dewan Komisaris ;

b. Direksi Bank ;

c. Pengawasan Bank;

d. Pihak terafiliasi.

Menurut Pasal 1 Ayat (22) Undang-Undang Perbankan Nomor 10 Tahun 1998, yang dimaksud pihak terafiliasi adalah:

1) Anggota dewan komisaris atau pengawasan, direksi, pejabat atau karyawan bank.

2) Anggota dewan komisaris atau pengawasan, direksi, pejabat atau karyawan bank, khusus bagi bank yang berbentuk hukum koperasi sesuai dengan peraturan perundang-undangan.

3) Pihak yang memberikan jasanya kepada bank yang bersangkutan termasuk konsultan, konsultan hukum, akuntan publik penilai.

4) Pihak yang berdasarkan ketentuan yang ditetapkan oleh Bank Indonesia turut mempengaruhi pengelolaan bank.

\section{Kapan Ketentuan Tentang Rahasia Bank Tidak Berlaku}

Ketentuan tentang kewajiban bank untuk menjaga rahasia tidak berlaku dalam hal-hal sebagai berikut :

a. Dalam rangka pembinaan dan pengawasan oleh bank Indonesia sebagai mana dimaksud dalam Pasal 30

Undang-Undang Perbankan Nomor 10 Tahun 1998 menentukan :

1) Bank wajib menyampaikan kepada Bank Indonesia segala keterangan, dan penjelasan mengenai usahanya menurut tata cara yang ditetapkan oleh Bank Indonesia.

2) Bank atas permintaan Bank Indonesia, wajib memberikan kesempatan bagi pemeriksaan buku-buku dan berkas-berkas yang ada padanya, serta wajib memberikan bantuan yang diperlukan dalam rangka memperoleh kebenaran dari segala keterangan, dokumen dan penjelasan yang dilaporkan oleh bank yang bersangkutan.

3) Keterangan tentang bank yang diperoleh berdasarkan ketentuan sebagaimana dimaksud dalam Ayat (1) dan Ayat (2) tidak diumumkan dan bersifat rahasia.

Kemudian Pasal 31 menentukan:

(1) Bank Indonesian melakukan pemeriksaan terhadap bank, baik secara berkala maupun setiap waktu apabila diperlukan.

(2) Bank atas permintaan Bank Indonesia, wajib memberikan kesempatan bagi pemeriksaan buku-buku dan berkas-berkas yang ada padanya, serta wajib memberikan bantuan yang diperlukan dalam rangka memperoleh kebenaran dari segala keterangan, dokumen dan penjelasan yang dilaporkan oleh bank yang bersangkutan.

(3) Keterangan tentang bank yang diperoleh berdasarkan ketentuan sebagaimana dimaksud dalam ayat (1) dan ayat (2) tidak diumumkan dan bersifat rahasia.

Kemudian Pasal 34 menentukan:

(1) Bank wajib menyampaikan kepada Bank Indonesia neraca dan perhitungan laba/rugi tahunan serta penjelasannya, serta laporan berkala lainnya, dalam waktu dan bentuk yang ditetapkan oleh Bank Indonesia.

(2) Neraca serta perhitungan laba/rugi tahunan sebagaimana dimaksud dalam ayat (1) wajib terlebih dahulu diaudit oleh akuntan publik.

(3) Tahun buku bank adalah tahun takwim.

b. Dalam rangka kepentingan perpajakan Pasal 41 Undang-Undang Perbankan Nomor 10 Tahun 1998:

1) Untuk kepentingan perpajakan Menteri berwenang mengeluarkan perintah tertulis kepada Bank agar memberikan keterangan dan memperlihatkan bukti-bukti tertulis serta surat-surat mengenai keadaan keuangan nasabah tertentu kepada pejabat pajak.

2) Perintah tertulis sebagaimana dimaksud dalam ayat (1), harus menyebutkan nama pejabat pajak dan nama nasabah wajib pajak yang dikehendaki keterangannya. 
c. Dalam rangka kepentingan peradilan dalam perkara pidana Pasal 42 Undang-undang Perbankan Nomor

10 Tahun 1998:

1) Untuk kepentingan peradilan dalam perkara pidana Menteri dapat memberi izin kepada polisi, jaksa atau hakim untuk memperoleh keterangan dari bank tentang keadaan keuangan tersangka/terdakwa pada bank.

2) Izin sebagaimana dimaksud dalam ayat (1) diberikan secara tertulis atas permintaan tertulis dari Kepada Kepolisian Republika Indonesia, Jaksa Agung, atau Ketua Mahkamah Agung.

3) Permintaan sebagai dimaksud dalam ayat (2) harus menyebutkan nama dan jabatan polisi, jaksa atau hakim, nama tersangka/terdakwa, sebab-sebab keterangan diperlukan dan hubungan perkara pidana yang bersangkutan dengan keterangan-keterangan yang diperlukan.

d. Dalam rangka perkara perdata antara bank dengan nasabahnya Pasal 43 Undang-Undang Perbankan Nomor 10 Tahun 1998:

"Dalam perkara perdata antara bank dengan nasabahnya direksi bank yang bersangkutan dapat menginformasikan kepada pengadilan tentang keadaan keuangan nasabah yang bersangkutan dan memberikan keterangan lain yang relevan dengan perkara tersebut."

e. Dalam rangka tukar-menukar informasi antara bank Pasal 44 Undang-Undang Perbankan Nomor 10 Tahun 1998:

"Dalam rangka tukar-menukar informasi antara bank, direksi bank dapat memberitahukan keadaan keuangan nasabahnya kepada bank lain."

Bank adalah satu lembaga yang keuangannya telah dikenal oleh masyarakat sejak beberapa abad silam, kedudukan bank lebih dilihat sebagai lembaga keperdataan yang bergerak dalam lapangan simpan pinjam, berdasarkan hal tersebut sesuai dengan teori badan hukum maka bank adalah salah satu subjek hukum secara normatif tunduk langsung pada ketentuan-ketentuan yang berkaitan dengan aturan keperdataan. Dalam aturan keperdataan ada beberapa norma dasar yang mengikat bank sebagai subyek hukum dalam melakukan perbuatan hukum ketentuan-ketentuan itu antra lain (Hariyanto, 2011) :

1. Asas Konsensualisme

Asas ini dapat disimpulkan dalam pasal 1320 ayat (1) KUH Perdata yang berbunyi :"Salah satu syarat sahnya perjanjian adalah kesepakatan kedua belah pihak. "ini mengandung makna, bahwa perjanjian pada umumnya tidak diadakan secara formal, tetapi cukup dengan adanya kesepakatan kedua belah pihak.

2. Asas Pacta Sunt Servanda

Asas Pacta Sunt Servanda berhubungan dengan akibat perjanjian hal ini dapat disimpulkan dalam Pasal 1338 ayat (1) KUH Perdata, yang berbunyi :

"Perjanjian yang secara sah berlaku sebagai Undang-undang". Ini mengandung makna bahwa setiap perjanjian diadakan oleh kedua belah pihak merupakan perbuatan yang sakral dan dikaitkan dengan unsur keagamaan.

3. Asas Kebebasan Berkontrak

Asas kebebasan berkontrak dapat dianalisis dari ketentuan pasal 1338 ayat (1) KUH Perdata, yang berbunyi :" Semua perjanjian yang dibuat secara sah berlaku sebagai Undang-undang bagi mereka yang membuatnya". Asas kebebasan berkontrak adalah suatu asas yang memberikan kebebasan kepada para pihak untuk :

a. Membuat atau tidak membuat perjanjian.

b. Mengadakan perjanjian dengan siapa pun.

c. Menentukan isi perjanjian perjanjian, pelaksanaan, dan persyaratannya.

d. Menentukan bentuknya perjanjian, yaitu tertulis atau lisan.

Di samping keempat asas itu, di dalam Lokakarya Hukum Perikatan yang diselenggarakan oleh Badan Pembinaan Hukum Nasional, Departemen Kehakiman dari Tanggal 17 sampai dengan Tanggal 19 Desember 1985 telah berhasil dirumuskan delapan asas hukum perikatan nasional. Ke delapan asas itu (Salim, 2001) :

1. Asas Kepercayaan

Setiap orang yang akan mengadakan perjanjian akan memenuhi setiap prestasi yang diadakan di antara mereka di belakang hari.

2. Asas Persamaan Hukum

Subyek hukum yang mengadakan perjanjian mempunyai kedudukan, hak, dan kewajiban yang sama dalam hukum, dan tidak dibeda-bedakan antara satu sama lain, walaupun subyek hukum itu berbeda warna kulit, agama, dan ras.

3. Asas Keseimbangan

Suatu asas yang menghendaki kedua belah pihak memenuhi dan melaksanakan perjanjian.

4. Asas Kepastian Hukum 
Perjanjian sebagai figur hukum harus mengandung kepastian hukum. Kepastian ini terungkap dari kekuatan mengikatnya perjanjian, yaitu sebagai undang-undang bagi yang membuatnya.

5. Asas Moral

Asas moral ini terikat dalam perikatan wajar, di mana suatu perbuatan sukarela dari seseorang tidak dapat menuntut hak baginya untuk menggugat prestasi dari pihak debitor.

6. Asas Kepatutan

Asas ini tertuang dalam pasal 1339 KUH Perdata. Asas ini berkaitan dengan ketentuan mengenai isi perjanjian.

7. Asas Kebiasaan

Suatu perjanjian tidak hanya mengikat untuk apa secara tegas diatur, akan tetapi juga hal-hal yang menurut kebiasaan lazim diikuti.

8. Asas Perlindungan

Bahwa antara debitur dan kreditur harus dilindungi oleh hukum namun yang perlu mendapat perlindungan itu seringkali adalah pihak debitur karena pihak debitur berada pada pihak yang paling lemah.

Bank merupakan suatu pihak yang tepat bagi suatu upaya menghimpun dana masyarakat, baik untuk investasi jangka pendek maupun investasi jangka panjang karena itu kegiatan yang dilakukan oleh bank maupun lembaga keuangan bukan bank dapat dirasakan dan dinikmati secara merata oleh seluruh masyarakat luas sehingga wajar apabila bank dengan lembaga bukan bank mempunyai peran yang sangat penting.

Dalam membangun ekonomi bangsa yang mempunyai peran serta salah satunya kedudukan bank akan sangat menentukan sebab apabila pengaturan sistem perbankan kita kuat maka negara ini tidak akan terkena krisis dilihat dari beberapa aspek seperti sistem pengawasan serta instrument legal yang mengatur hal itu. Proses perbaikan yang dilakukan terhadap sistem perbankan kita telah menunjuk perubahan yang mendasar bagi perkembangan sistem perbankan kita, mulai dari diperketatnya sistem pengawasan serta dikeluarkanya aturan-aturan legal yang lebih memberikan kepastian hukum untuk menjadikan sistem perbankan yang sehat dan bersih.

Saat ini peraturan pokok tentang perbankan diatur dalam Undang-Undang Nomor 10 Tahun 1998 yang merupakan perubahan dari Undang-Undang Nomor 7 Tahun 1992. Perubahan tersebut merupakan penyesuaian kebijakan dibidang ekonomi dalam menghadapi perkembangan perekonomian nasional yang senantiasa bergerak cepat, kompetitif, dan terintegrasi dengan tantangan yang semakin kompleks serta sistem keuangan yang semakin maju.

\section{Rumusan Masalah}

Berdasarkan latar belakang di atas yang hendak dikaji lebih lanjut oleh penulis yakni "Bagaimana peran bank sebagai lembaga Perantara (Intermediary) ditinjau dari Undang-Undang Nomor 10 Tahun $1998 ? "$

\section{Tujuan Penelitian}

Tujuan penelitian ini adalah untuk mengetahui bagaimanakan peran bank sebagai lembaga perantara (intermediary) ditinjau dari Undang-Undang Nomor 10 Tahun 1998.

\section{METODE PENELITIAN}

Penelitian ini merupakan penelitian hukum normatif yaitu dengan mengkaji/ menganalisis bahan hukum primer dan bahan hukum sekunder dengan memahami hukum sebagai seperangkat peraturan atau norma-norma positif di dalam sistem perundang-undangan yang mengatur berkaitan dengan masalah yang diteliti.

\section{HASIL DAN PEMBAHASAN}

\section{Peran Bank Sebagai Lembaga Perantara (Intermediary) Ditinjau Dari Undang-Undang Nomor 10 Tahun 1998.}

Sebagai lembaga keuangan yang berorentasi bisnis, bank juga melakukan berbagai kegiatan, seperti menghimpun, memberikan kredit, serta memberikan jasa-jasa keuangan. Sebagai lembaga keuangan, kegiatan perbankan yang paling pokok adalah membeli uang dengan cara menghimpun dana dari masyarakat luas kemudian menjual uang yang berhasil dihimpun dengan cara menyalurkan kembali kepada masyarakat melalui pemberian pinjaman atau kredit. Dari kegiatan jual beli uang itulah bank memperoleh keuntungan 
yaitu dari selisih harga beli (bunga simpanan) dengan harga jual (bunga pinjaman) disamping itu kegiatan bank lainnya dalam rangka mendukung kegiatan menghimpun dan menyalurkan dana adalah memberikan jasa-jasa lainnya kegiatan ini ditunjuk untuk memperlancar kegiatan menghimpun dan menyalurkan dana.

Ketentuan peraturan perundang-undangan yang berlaku mengatur bahwa kegiatan usaha perbankan Indonesia harus sesuai dengan jenis bank yaitu bahwa jenis bank menentukan kegiatan usaha yang dapat dilakukannya. Bank Konvensional akan jauh berbeda dengan usaha yang dilakukan oleh bank berdasarkan prinsip syariah, begitu pula kegiatan usaha Bank umum akan banyak berbeda pula dengan usaha yang dilakukan oleh Bank Perkreditan Rakyat. Berdasarkan Pasal 6 sampai dengan Pasal 20 Undang-Undang Nomor 10 Tahun 1998 tentang Perubahan Atas Undang-Undang Nomor 7 Tahun 1992 tentang Perbankan, disebutkan bahwa pada prinsipnya di Indonesia setiap usaha yang melakukan kegiatan menghimpun dana dari masyarakat dalam bentuk simpanan, wajib terlebih dahulu memperoleh izin usaha sebagai Bank Umum atau Bank Perkreditan Rakyat dari Pimpinan Bank Indonesia, diatur dengan undang-undang tersendiri. Kewajiban untuk memperoleh izin usaha sebagai Bank Umum atau Bank Perkreditan Rakyat adalah karena kegiatan menghimpun dana dari masyarakat oleh bank pada dasarnya merupakan kegiatan yang perlu diawasi karena berkaitan dengan kepentingan masyarakat yang menyimpan dananya di bank.

Penghimpunan dana merupakan jasa ditawarkan dunia perbankan baik Bank Umum maupun Bank Perkreditan Rakyat sebagai salah satu lembaga keuangan di mana kegiatan penghimpunan dana tersebut adalah merupakan salah satu peran strategis yang dapat menunjang kelancaran perekonomian dan dana yang terhimpun disalurkan kembali oleh Bank untuk peningkatan taraf hidup rakyat. Produk yang ditransaksikan dapat berupa sekuritas primer (saham, obligasi, promis) serta sekuritas sekunder (giro, tabungan, deposito, polis, program pensiun, saham dan sebagainya). Kegiatan BPR pada dasarnya sama dengan kegiatan bank umum, hanya yang menjadi perbedaan adalah jumlah jasa bank yang dilakukan BPR jauh lebih sempit. BPR dibatasi berbagai persyaratan sehingga tidak dapat berbuat seleluasa bank umum keterbatasan kegiatan BPR juga dikaitkan dengan misi pendirian BPR itu sendiri. Adapun kegiatan perbankan sebagai pihak perantara (intermediary) yakni :

1. Kegiatan perbankan dalam penghimpunan dana bank (funding);

2. Kegiatan perbankan dalam penggunaan dana bank melalui pemberian kredit (lending);

3. Kegiatan bank dalam memberikan jasa-jasa bank (services).

Di Indonesia lembaga keuangan bank memiliki misi, dan fungsi yang khusus, jadi perbankan Indonesia selain memiliki fungsi yang lazim seperti apa yang telah diuraikan sebelumnya, juga memiliki fungsi yang diarahkan sebagai agen pembangunan (agent of development), yaitu sebagai lembaga yang bertujuan guna mendukung pelaksanaan pembangunan nasional dalam rangka meningkatkan pemerataan pembangunan dan hasil-hasilnya, pertumbuhan ekonomi dan stabilitas nasional, kearah peningkatan taraf hidup rakyat banyak.

Fungsi bank sebagai lembaga intermediasi terutama dalam hal kegiatan penyaluran kredit mempunyai peranan yang sangat penting bagi pergerakan perekonomian secara keseluruhan dan memfasilitasi pertumbuhan ekonomi. Pemberian kredit merupakan aktivitas bank yang paling utama dalam menghasilkan keuntungan, namun juga memberikan risiko yang terbesar kepada bank. Salah satu alasan terkonsentrasinya usaha bank dalam penyaluran kredit adalah sifat usaha bank sebagai lembaga perantara (intermediary) antara unit surplus dengan unit defisit, dimana sumber dana perbankan berasal masyarakat sehingga secara moral mereka harus menyalurkan kembali kepada masyarakat dalam bentuk kredit (Taswan, 2010). Selain itu fungsi intermediasi juga dapat digunakan untuk mengukur tingkat efisiensi perbankan, dimana efisiensi bank merupakan salah satu indikator untuk menganalisa kinerja (performance) suatu bank dan juga sebagai sarana untuk lebih meningkatkan efektifitas kebijakan moneter.

Bank sebagai salah satu lembaga keuangan yang paling penting dan memiliki peranan yang sangat besar dalam kehidupan masyarakat. Dalam menjalankan perananya maka bank bertindak sebagai salah satu bentuk lembaga keuangan yang bertujuan memberikan kredit, dan jasa-jasa keuangan lainnya. Adapun pemberian kredit itu dilakukan baik dengan modalnya sendiri, atau dengan dana-dana yang dipercayakan oleh pihak ketiga maupun dengan jalan memperedarkan alat-alat pembayaran baru berupa uang giral. Dari pengertian di atas, maka kita melihat bahwa bank menjalankan perniagaan dana atau uang. Jadi tegasnya bank sangat erat kaitanya dengan kegiatan peredaran uang, dalam rangka melancarkan seluruh aktivitas keuangan masyarakat. Bank sebagai lembaga keuangan mempunyai peran yang penting dalam sistem keuangan :

1. Pengalihan Aset (Aset Transmutiation)

Bank dan lembaga bukan bank akan memberikan pinjaman kepada pihak yang membutuhkan dana dalam jangka waktu tertentu yang disepakati. Sumber dana tersebut diperoleh dari pemilik dana yaitu dari unit surplus yang jangka waktunya dapat diatur sesuai dengan keinginan pemilik dana. Dalam hal ini bank dan lembaga keuangan bukan bank telah berperan sebagai pengalih aset dari unit surplus (lender) kepada unit defisit (borrowers). 


\section{Transaksi (Transaction)}

Bank dan lembaga bukan bank memberikan berbagai kemudahan kepada pelaku bisnis untuk melakukan transaksi barang dan jasa. Produk-produk yang dikeluarkan oleh Bank dan lembaga keuangan bukan bank (giro, tabungan, deposito dan sebagainya) merupakan pengganti dari uang dan dapat digunakan sebagai alat pembayaran.

3. Likuditas (Liquidity)

Unit surplus dapat menempatkan dana yang dimilikinya dalam bentuk produk-produk berupa giro, deposito, tabungan dan sebagainya. Produk-produk tersebut masing-masing mempunyai tingkat likuditas yang berbeda-beda. Untuk kepentingan likuiditas pemilik dana, mereka dapat menempatkan dananya sesuai dengan kebutuhan dan kepentinganya.

4. Efisiensi (Efficiency)

Bank dan lembaga keuangan bukan bank dapat menurunkan biaya transaksi dengan jangkauan pelayananya. Peranan Bank dan lembaga keuangan bukan bank sebagai broker adalah mempertemukan pemilik dan pengguna dana. Lembaga keuangan memperlancar dan mempertemukan pihak-pihak yang saling membutuhkan.

Peran bank dalam menunjang kegiatan pembangunan nasional atau regional :

1. Peranan bank dalam pemberantasan kemiskinan

Peranan bank juga dapat memberantas kemiskinan dimana dapat melalui banyak saranan dan program baik yang bersifat langsung maupun tidak langsung, yang berupa transfer payment dari pemerintah misalnya program pangan, kesehatan, pemukiman, pendidikan, keluarga berencana, maupun usaha yang bersifat produktif misalnya melalui pinjaman dalam bentuk micro credit.

2. Peranan dalam pengembangan ekonomi kelautan

Perbankan dapat menyediakan kredit segmen komersial untuk pembiayaan proyek-proyek pembangunan infrastruktur dan aktifitas yang berkelanjutan seperti pembiayaan pelayaran.

\section{PENUTUP}

\section{Simpulan}

Bank sebagai salah satu lembaga keuangan yang paling penting dan memiliki peranan besar dalam kehidupan masyarakat memiliki fungsi sebagai :

1. Pedagang dana (money lender) yaitu wahana yang dapat menghimpun dan menyalurkan dana masyarakat secara efektif dan efisien. Bank menjadi tempat untuk penitipan, dan penyimpanan uang yang dalam prakteknya sebagai tanda penitipan dan penyimpanan uang tersebut, maka kepada penitip dan penyimpan diberikan selembar kertas dan tanda bukti. Sedangkan dalam fungsinya sebagai penyalur dana, maka bank memberikan kredit atau memasukkannya kedalam bentuk surat-surat berharga.

2. Lembaga yang melancarkan transaksi perdagangan, dan pembayaran uang. Bank bertindak sebagai penghubung antara nasabah yang satu dengan yang lainnya jika keduanya melakukan transaksi. Dalam hal ini kedua orang tersebut tidak secara langsung melakukan pembayaran tetapi cukup memerhatikan pada bank untuk menyelesaikannya.

\section{Saran}

Adapun saran dalam penelitian ini sebagai berikut:

1. Bank menjadi lembaga tempat penyimpanan dana yang efektif dan efesien.

2. Jika melakukan transaksi keuangan, maka bank menjadi pilihan yang tepat sebagai perantara transaksi tanpa mempertemukan pihak yang bertransaksi.

\section{DAFTAR PUSTAKA}

Departemen Pendidikan dan Kebudayaan Pusat Pembinaan dan Pengembangan Bahasa Kamus Besar Bahasa Indonesia. (1995). Edisi II. Jakarta: Balai Pustaka

Salim. HS. (2001). Pengantar Hukum Perdata Tertulis (BW). Jakarta: PT Sinar Grafika

Undang-Undang Dasar 1945.

Kitab Undang-Undang Hukum Perdata.

Undang - Undang Nomor 10 Tahun 1998 Tentang Perubahan Atas Undang-Undang Nomor 7 Tahun 1992 Perbankan. Lembaran Negara Republik Indonesia Tahun 1998 Nomor 182.

M. Hariyanto. (2011). Asas-Asas Perjanjian, 05 November 2020, URL http:/www.M.Hariyanto.com. 